DOI: https://doi.org/10.18371/fp.2(34).2019.178495

УДК 336.77

\title{
БАНКІВСЬКЕ КРЕДИТУВАННЯ ФІЗИЧНИХ ОСІБ В УКРАЇНІ: СУЧАСНИЙ СТАН ТА ПЕРСПЕКТИВИ РОЗВИТКУ
}

\author{
ЖЕЖЕРУН Юлія Володимирівна \\ к.е.н., доцент кафедри фінансів та банківської справи \\ Черкаського інституту \\ ДВНЗ «Університет банківської справи» \\ ORCID ID: http://orcid.org/0000-0001-8200-730X \\ e-mail: Julia_Dm@ukr.net
}

\begin{abstract}
Анотація. $\quad y$ статті досліджено сутність та види банківського кредитування фізичних осіб. Проведено аналіз динаміки та структури кредитів, наданих фізичним особам, банками у 2009-2018 рр. за циільовим спрямуванням, за термінами кредитування, за видом валют. Проаналізовано динаміку прочентних ставок за новими кредитами. Виявлено ризики та досліджено перспективи розвитку банківського кредитування фізичних осіб в Україні.

Ключові слова: банківське кредитування фізичних осіб, споживче кредитування, іпотечні кредити, валютні ризики, непрацюючі кредити.
\end{abstract}

Постановка проблеми. В Україні більшість населення не спроможна купувати товари тривалого користування за рахунок поточних доходів. За результатами досліджень проекту USAID «Трансформація фінансового сектору», охоплення населення фінансовими послугами залишається низьким, близько 55\% українців не мають коштів у банках і лише $28 \%$ користуються кредитами. Головними причинами називають низькі доходи та недовіру до банківської системи. Для порівняння, через недовіру не тримали
Аннотация. $B$ cmaтье исследована сущุность и виды банковского кредитования физических лии. Проведен анализ динамики и структуры кредитов, предоставленных физическим лииам, банками в 2009-2018 г2. по целевому назначению, по срокам кредитования, по виду валют. Проанализирована динамика прочентных ставок по новым кредитам. Выявлено риски и исследованы перспективы развития банковского кредитования физических лии в Украине.

Ключевые слова: банковское кредитование физических лии, потребительское кредитование, ипотечные кредиты, валютные риски, неработающие кредиты.

кошти у банках в 2015 році - 19\%, в 2018 році $45 \%$.

Значну роль у задоволенні соціальних потреб, підвищенні рівня життя та формуванні платоспроможного попиту населення відіграє банківське кредитування фізичних осіб, яке, у свою чергу, впливає на забезпечення соціально-економічного розвитку країни, полегшуючи процес реалізації продукції, прискорюючи отримання прибутку і доходів державного бюджету. Тож на сьогодні $є$ актуальним дослідження проблем банківського кредитування 
фізичних осіб.

Аналіз останніх досліджень і публікацій. 3 огляду на значимість, проблеми банківського кредитування фізичних осіб досліджувались такими вітчизняними та зарубіжними науковцями: А. Мороз, А. Москальов, М. Пуховкіна, М. Савлук, Я. Чайковський та інші. Погляди вчених-економістів зводяться здебільшого до опрацювання окремого виду банківського кредитування фізичних осіб - споживчого кредитування. При цьому банківське кредитування фізичних осіб загалом залишається не достатньо дослідженим.

Метою статті $є$ дослідження сучасного стану банківського кредитування фізичних осіб, виявлення ризиків та перспектив його розвитку в Україні.

Виклад основного матеріалу. Банківський кредит для фізичних осіб $є$ формою економічних відносин між банком та позичальником, яка передбачає надання населенню на умовах повернення, строковості та платності нагромаджених в банку тимчасово вільних грошових ресурсів [1]. Залучення банківського кредиту $є$ класичною технологією запозичення необхідних фінансових ресурсів. Кредит може надаватись позичальнику готівково через касу банку або безготівково, шляхом перерахування коштів з позичкового рахунку на банківський (поточний) рахунок. Рішення про надання кредиту приймається 3 урахуванням фінансово-майнового стану позичальника, його клієнтської та кредитної історії, інформації про доходи та ділову репутацію, достатності та ліквідності забезпечення повернення кредиту. Умови кредитування визначаються 3 урахуванням терміну та цільового спрямування кредиту.

Термін «фізична особа» у цивільному законодавстві [2, 3] застосовується для позначення людини (громадянина України, іноземця, особи без громадянства), в т.ч. фізичної особисуб'єкта підприємницької діяльності, як учасника правових відносин.

Слід зазначити, що в більшості літературних джерел поняття «банківське кредитування фізичних осіб» ототожнюється 3 поняттям «споживче кредитування». На нашу думку, ці поняття не є тотожними, оскільки споживче кредитування $є$ одним із видів банківського кредитування фізичних осіб.

Як зазначають М. Савлук, А. Мороз, М. Пуховкіна, кредитування фізичних осіб - це форма економічних відносин між позичальником та банком, яка передбачає надання населенню на умовах повернення, строковості, платності та забезпечення акумульованих в банку тимчасово вільних грошових коштів [4]. Я. Чайковський визначає споживчий кредит як сукупність відносин, пов'язану з рухом позичкового капіталу між кредитором і позичальником - фізичною особою - резидентом, у національній грошовій одиниці або товарній формі на основі укладеного кредитного договору на принципах забезпеченості, повернення, терміновості, платності та цільової спрямованості для забезпечення споживання [5]. Тому під банківським кредитуванням фізичних осіб будемо мати на увазі правовідносини щодо надання, обслуговування та повернення банком кредитів, наданих фізичним особам (в т.ч. фізичним особам- 
суб’єктам підприємницької діяльносTi).

Банківські кредити фізичними особами спрямовуються переважно на споживчі потреби, на придбання, бу- дівництво та реконструкцію нерухомості, в т.ч. іпотечні кредити тощо. Класифікацію банківських кредитів, наданих фізичним особам можна здійснювати за різними ознаками (рис. 1).

\begin{tabular}{|c|c|}
\hline $\begin{array}{c}\text { Залежно від наявності } \\
\text { забезпечення }\end{array}$ & $\begin{array}{l}\text { - забезпечені (застава, гарантія, поручительство, } \\
\text { страхування); } \\
\text { - бланкові або незабезпечені. }\end{array}$ \\
\hline $\begin{array}{c}\text { Залежно від терміну } \\
\text { кредитування }\end{array}$ & $\begin{array}{l}\text { - короткострокові (до } 1 \text { року); } \\
\text { - середньострокові (від } 1 \text { до } 5 \text { років); } \\
\text { - довгострокові(більше } 5 \text { років). } \\
\end{array}$ \\
\hline За видом валют & $\begin{array}{l}\text { • в національній валюті; } \\
\text { • в іноземній валюті. }\end{array}$ \\
\hline \multirow[t]{2}{*}{$\begin{array}{c}\text { Залежно від способу сплати } \\
\text { відсотків }\end{array}$} & \multirow{2}{*}{$\begin{array}{l}\text { • сплата відсотків авансом, тобто у момент } \\
\text { надання кредиту; } \\
\text { - погашення відсотків протягом терміну } \\
\text { користування кредитом: щомісяця, щоквартально } \\
\text { та інші; } \\
\text { • сплата відсотків вкінці терміну користування } \\
\text { кредиту, тобто у момент погашення. } \\
\end{array}$} \\
\hline & \\
\hline За цільовим спрямуванням & \multirow{2}{*}{$\begin{array}{l}\text { • споживчі кредити; } \\
\text { • на придбання, будівництво та реконструкцію } \\
\text { нерухомості; } \\
\text { • іпотечні кредити; } \\
\text { • інші кредити. }\end{array}$} \\
\hline & \\
\hline
\end{tabular}

Рис. 1. Класифікація банківських кредитів, наданих фізичним особам Джерело: складено автором

Слід зазначити, що у вітчизняному законодавстві немає єдиного визначення економічної категорії «споживчий кредит», що має негативний вплив на його організацію. Так, у Законі України «Про споживче кредитування» наведено таке визначення: «Споживчий кредит - грошові кошти, що надаються споживачу (позичальникові) на придбання товарів (робіт, послуг) для задоволення потреб, не пов'язаних з підприємницькою, незалежною професійною діяльністю або виконанням обов'язків найманого працівника» [6]. Тобто, споживчий кредит дозволяе позичальнику отри- мати грошові кошти для задоволення виключно особистих потреб. Таке визначення не повне, оскільки мова йде лише про грошову форму кредиту не враховуючи товарної форми. В свою чергу, у Законі України «Про захист прав споживачів» зазначено, що: «Споживчий кредит - кошти, що надаються кредитодавцем (банком або іншою фінансовою установою) споживачеві на придбання продукції» [7]. У цьому Законі акцентується увага на наданні споживчих кредитів банківськими або іншими фінансовими установами, зокрема кредитними спілками, ломбардами. Однак споживчий 
кредит також можуть надавати підприємства торгівлі та сфери послуг.

Кредити на придбання транспортних засобів $є$ різновидом споживчих кредитів. Кредитні кошти в безготівковій формі зараховуються на поточний рахунок позичальника 3 подальшим перерахуванням на банківський рахунок продавця транспортного засобу. Кредити надаються здебільшого на умовах щомісячного погашення кредиту та процентів. Розмір процентної ставки за кредитними програмами буде відрізнятися в залежності від суми авансового внеску та терміну кредитування. Чим менше термін дії кредитного договору, тим нижче процентна ставка за кредитом. Обов'язковими умовами надання кредиту $є$ нотаріальне посвідчення договору застави транспортного засобу, страхування транспортного засобу, наявність офіційних джерел доходів.

Іпотечні кредити з 2009 р. надається фізичним особам виключно в національній валюті для придбання нерухо- мого майна. До іпотечних кредитів включаються кредити, що мають декілька видів забезпечення, серед яких найбільшим за вартістю є: майнові права на майбутнє нерухоме майно житлового фонду; майнові права на інше майбутнє нерухоме майно; нерухоме майно житлового фонду; інше нерухоме майно. Обов'язковими умовами надання коштів $\epsilon$ нотаріальне посвідчення договору застави (коефіцієнт покриття кредиту заставою від 100\%), порука третіх осіб, страхування нерухомості, страхування життя позичальника, наявність офіційних джерел погашення кредиту та процентів.

У 2018 р. банківські кредити фізичним особам становили лише 17,59\% кредитного портфеля вітчизняних банків (рис. 2) або 5,7\% ВВП, що майже втричі нижче, ніж до кризи 2014-2015 років. Боргове навантаження на фізичних осіб залишається низьким і становить лише 9,1\% наявного річного доходу [8].

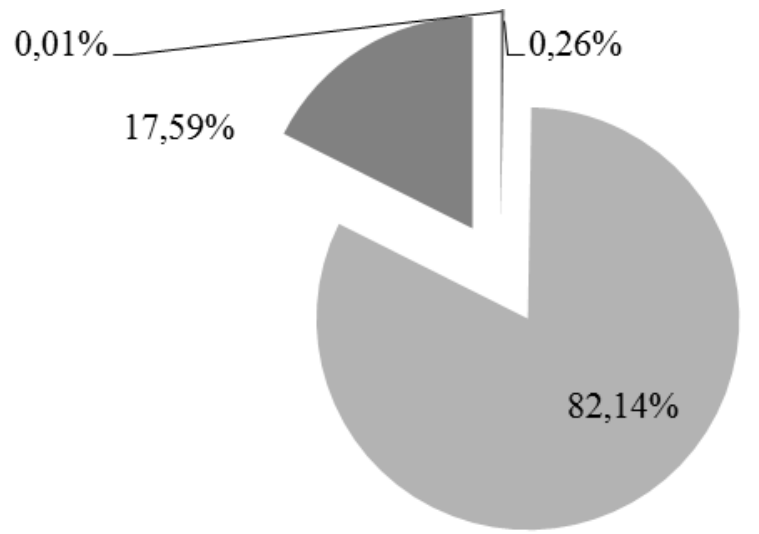

$$
\begin{aligned}
& \text { кредити, надані органам державної } \\
& \text { влади } \\
& \text { кредити, надані суб єктам } \\
& \text { господарювання } \\
& \text { кредити, надані фізичним особам } \\
& \text { кредити, надані небанківським } \\
& \text { фінансовим установам }
\end{aligned}
$$

Рис. 2. Частка кредитів, наданих фізичним особам у загальному кредитному портфелі банків у 2018 р.

Джерело: складено автором за даними [9]

Кредитування фізичних осіб в Україні здійснюють 69 банків із 77 зареєст- рованих, серед яких найбільші обсяги мають: АТ КБ «Приватбанк», АТ «Ук- 
рсоцбанк», АТ «Альфа-банк», АТ банк», АТ «Кредобанк» та інші (табл. «ПУМБ», АТ «ОТП банк», АТ «Оща- 1). дбанк», АТ «Райффайзен Банк Аваль»,

АТ «Укрсиббанк», АТ «Універсал

Таблиця 1

Топ-10 банків за обсягом кредитування фізичних осіб у 2018 p.

\begin{tabular}{|c|c|c|c|c|}
\hline Назва банка & $\begin{array}{c}\text { Обсяг кредитів, } \\
\text { наданих фізич- } \\
\text { ним особам, млн. } \\
\text { грн. }\end{array}$ & $\%$ & $\begin{array}{c}\text { Обсяг кредитів, нада- } \\
\text { них фізичним особам } \\
\text { без врахування резер- } \\
\text { вів, млн. грн. }\end{array}$ & $\%$ \\
\hline АТ КБ «ПриватБанк» & 67383 & 34,23 & 38976 & 34,19 \\
\hline АТ «Укрсоцбанк» & 25577 & 12,99 & 5192 & 4,55 \\
\hline АТ «Альфа-банк» & 15820 & 8,04 & 12333 & 10,82 \\
\hline АТ «ПУМБ» & 11601 & 5,89 & 8336 & 7,31 \\
\hline АТ «ОТП банк» & 9467 & 4,81 & 6053 & 5,31 \\
\hline АТ «Ощадбанк» & 8944 & 4,54 & 5412 & 4,75 \\
\hline АТ «Райффайзен Банк Аваль» & 7057 & 3,58 & 4771 & 4,18 \\
\hline АТ «Укрсиббанк» & 6637 & 3,37 & 4357 & 3,82 \\
\hline АТ «Універсал банк» & 5776 & 2,93 & 3813 & 3,34 \\
\hline АТ «Кредобанк» & 4340 & 2,20 & 4012 & 3,52 \\
\hline Банківський сектор загалом & 196863 & 100,0 & 114004 & 100,0 \\
\hline
\end{tabular}

Джерело: складено автором за даними [9]

Серед банківських кредитів, наданих фізичним особам, за цільовим спрямуванням у 2009-2018 рр. найбільшу частку займали споживчі кредити (рис. 3). 3 точки зору ліквідності та прибутковості споживче кредитування $\epsilon$ найбільш привабливим для банків, адже не вимагає довгострокових ресурсів та дозволяє підтримувати високу чисту процентну маржу. Так, у 2018 р. питома вага споживчих кредитів становила $75,4 \%$, в т.ч. на придбання транспортних засобів - 6,54\%, кредити на придбання, будівництво та реконструкцію нерухомості - 22,11\%, інші кре- дити $-2,5$ \%. При цьому із загальної суми іпотечні кредити становили $21,04 \%$.

Упродовж 2009-2017 рр. найбільшу частку в кредитах, наданих фізичним особам, займали довгострокові кредити терміном більше 5 років (від $44 \%$ до 70\% упродовж досліджуваного періоду). Переважну більшість яких становили іпотечні кредити. Однак у 2018 р. тенденція змінилась на користь короткострокового кредитування за рахунок скорочення обсягів іпотечного кредитування в 3,4 рази (рис. 4). 


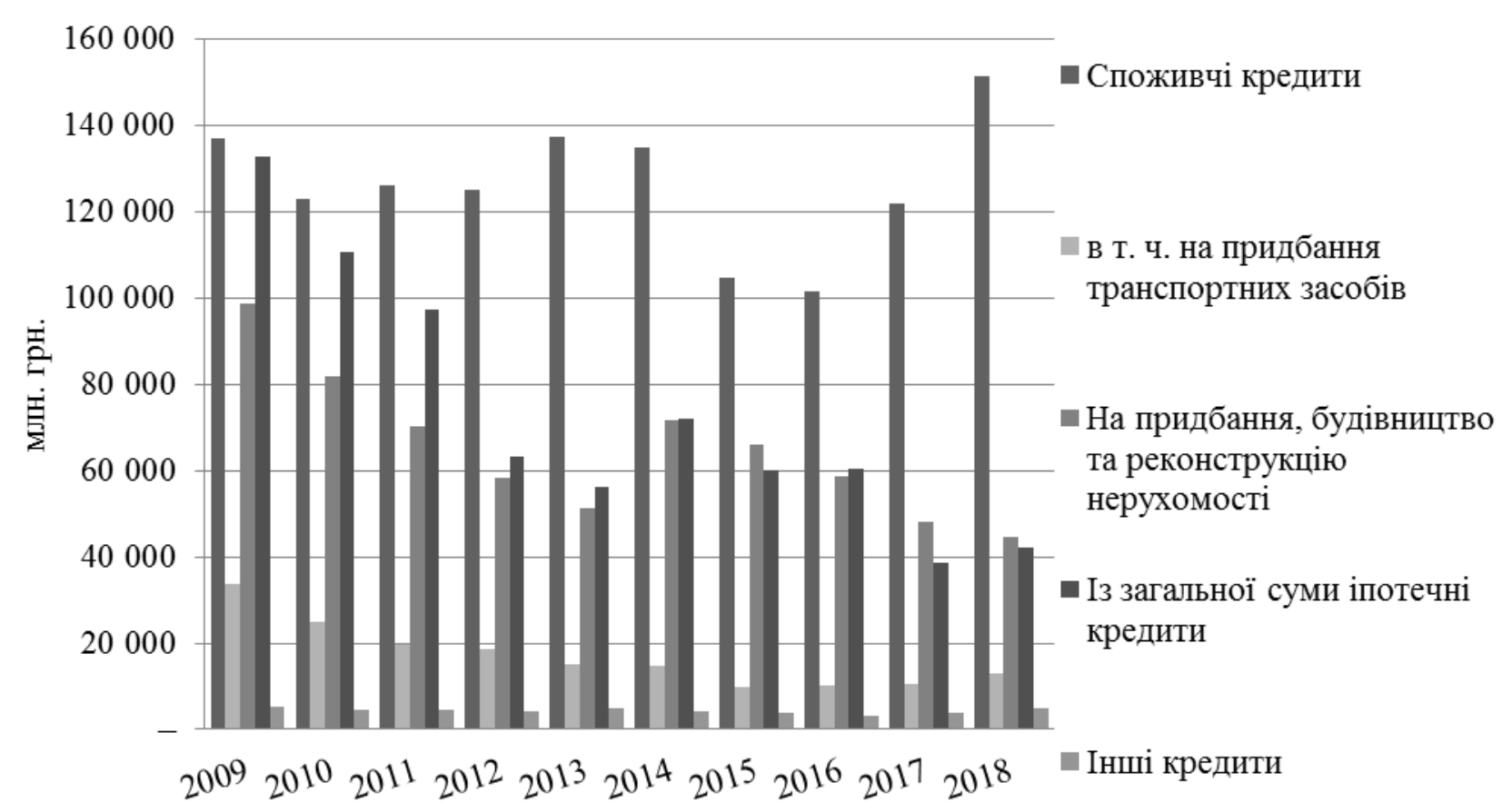

Рис. 3. Динаміка та структура банківських кредитів, наданих фізичним особам за цільовим спрямуванням у 2009-2018 pp.

Джерело: складено автором за даними [10]

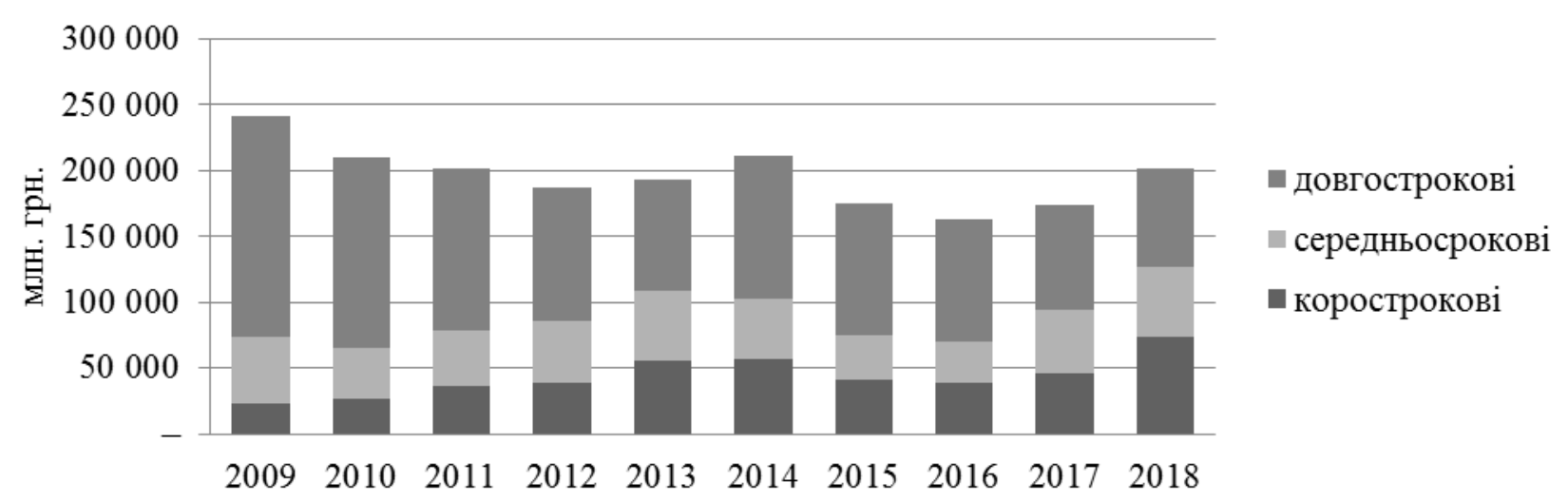

Рис. 4. Динаміка банківських кредитів, наданих фізичним особам за термінами кредитування у 2009-2018 pp.

Джерело: складено автором за даними [10]

Що стосується валютної структури кредитів, наданих фізичним особам банками України, у 2009-2018 pр. вона також змінилась. Якщо у 2009 р.
174580 млн. грн. або 72,37\% становили кредити в іноземній валюті, то в 2018 р. 140012 млн. грн. або 69,62\% в національній валюті (рис. 5). 


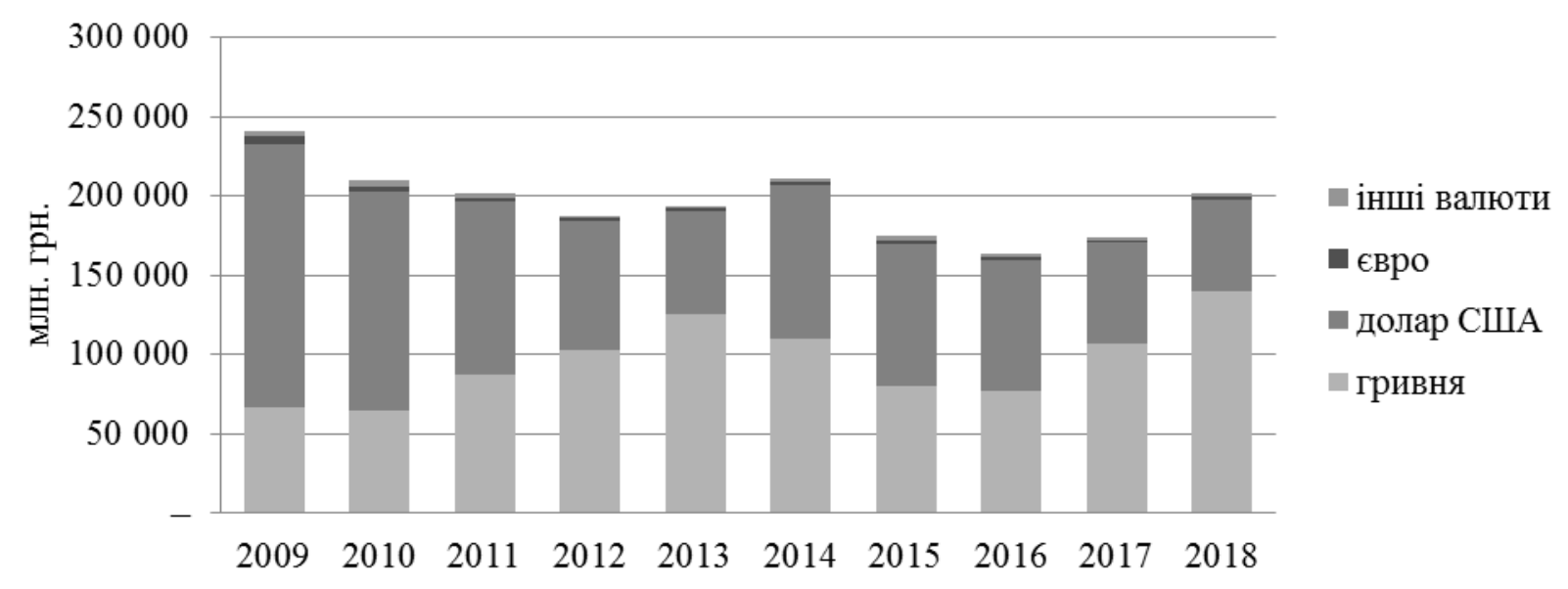

Рис. 5. Динаміка банківських кредитів, наданих фізичним особам за видом валют у 2009-2018 pp.

Джерело: складено автором за даними [10]

Зміни термінів та валютної структури кредитів пов'язані з девальвацією національної валюти, введенням 3 2009 р. Національним банком України обмежень на видачу нових валютних кредитів фізичним особам (Закон України «Про внесення змін до деяких законів України 3 метою подолання негативних наслідків фінансової кри3и» [11]) та поступовим погашенням вже виданих. Крім того, в 2016 р. прийнято Закон України «Про споживче кредитування», відповідно до п. 4. ст. 3 якого надання (отримання) споживчих кредитів в іноземній валюті на території України забороняється [5].

Привабливість кредитування фізичних осіб для банків зумовлена суттєво вищою дохідністю порівняно з корпоративними кредитами. Середня процентна ставка за корпоративними кредитами у 2018 р. становила $16,1 \%$, в той час як за кредитами, наданими фізичним особам - 30,4\%. За термінами погашення найвищу процентну ставку мають середньострокові кредити $33,5 \%$, за видами валют - кредити в національній валюті - 30,4\% (табл. 2).

Крім того, регуляторні вимоги до оцінки ризику кредитування фізичних осіб є м'якшими. Єдиний критерій, який банки постійно відстежують для оцінювання якості кредитів - це частка непрацюючих кредитів. Частка непрацюючих кредитів в кредитному портфелі банків в 2018 р. становила $54,54 \%$, в т.ч. в кредитах корпоративному сектору - 56,03\%, в кредитах, наданих фізичним особам - 53,51\%, в міжбанківських кредитах - 6,22\%, в кредитах органам державної влади та місцевого самоврядування - 0,69\%. Загалом за гривневими кредитами, наданими фізичним особам, частка непрацюючих кредитів складала 26,24\% і була значно нижчою, ніж за валютними кредитами -95,58\%. 
Таблиия 2

Процентні ставки за новими кредитами, наданими фізичним особам у $2009-2018$ pp.

\begin{tabular}{|c|c|c|c|c|c|c|}
\hline \multirow{2}{*}{ Період } & \multirow{2}{*}{$\begin{array}{c}\text { Усього, } \\
\%\end{array}$} & $\begin{array}{c}\text { коротко- } \\
\text { строкові }\end{array}$ & $\begin{array}{c}\text { середньо- } \\
\text { строкові }\end{array}$ & $\begin{array}{c}\text { довго- } \\
\text { строкові }\end{array}$ & $\begin{array}{c}\text { в національній } \\
\text { валюті }\end{array}$ & $\begin{array}{c}\text { в іноземній } \\
\text { валюті }\end{array}$ \\
\hline 2009 & 22,3 & 19,7 & 21,8 & 17,4 & 24,3 & 16,2 \\
\hline 2010 & 25,2 & 20,4 & 23,5 & 16,0 & 26,4 & 13,0 \\
\hline 2011 & 26,5 & 22,2 & 25,5 & 16,3 & 27,3 & 12,3 \\
\hline 2012 & 27,4 & 25,4 & 29,3 & 18,4 & 27,7 & 11,8 \\
\hline 2013 & 27,3 & 25,9 & 28,5 & 20,7 & 27,5 & 12,2 \\
\hline 2014 & 26,8 & 27,1 & 26,8 & 20,5 & 26,9 & 12,7 \\
\hline 2015 & 28,1 & 29,1 & 30,5 & 13,1 & 28,3 & 14,2 \\
\hline 2016 & 30,6 & 32,6 & 31,7 & 16,4 & 30,7 & 14,3 \\
\hline 2017 & 29,1 & 29,4 & 29,5 & 21,6 & 29,2 & 16,0 \\
\hline 2018 & 30,4 & 30,6 & 33,5 & 19,8 & 30,4 & 11,6 \\
\hline
\end{tabular}

Крім того, регуляторні вимоги до оцінки ризику кредитування фізичних осіб є м'якшими. Єдиний критерій, який банки постійно відстежують для оцінювання якості кредитів - це частка непрацюючих кредитів. Частка непрацюючих кредитів в кредитному портфелі банків в 2018 р. становила $54,54 \%$, в т.ч. в кредитах корпоративному сектору - 56,03\%, в кредитах, наданих фізичним особам $-53,51 \%$, в міжбанківських кредитах - 6,22\%, в кредитах органам державної влади та місцевого самоврядування - 0,69\%. Загалом за гривневими кредитами, наданими фізичним особам, частка непрацюючих кредитів складала 26,24\% i була значно нижчою, ніж за валютними кредитами $-95,58 \%$.

Таким чином, проведений аналіз показав, що більшість кредитів, наданих фізичним особам - це споживчі кредити $(75,4 \%)$. Така структура властива не тільки Україні. У країнах із подібним рівнем розвитку фінансового сектору також переважають неза- безпечені короткострокові споживчі кредити із високими процентними ставками. Це пов'язано з тим, що банківське кредитування фізичних осіб $\epsilon$ високодохідним та ризиковим видом діяльності. Через девальвацію національної валюти, розвиток інфляційних процесів, зменшення реальної заробітної плати, низьку платоспроможність населення, високі процентні ставки за кредитами значною залишається частка непрацюючих кредитів, наданих фізичним особам в іноземній валюті. При цьому конкуренція серед банків у споживчому кредитуванні зростає - це неминуче призведе до зниження вимог до позичальників. Натомість надання забезпечених кредитів відновлюється повільно. Наприклад, для стабільного зростання іпотеки потрібне дешеве довгострокове фондування, якого бракує в Україні. Однак, у банків, зосереджених у цьому сегменті кредитування, немає суттєвих розривів у строковості активів та пасивів. Валютний ризик знижується, оскільки з 2009 ро- 
ку валютне кредитування фізичних осіб обмежене законом. Відповідно частка валютних кредитів, наданих фізичним особам за останні 10 років значно знизилась (до 30,38\%).

Для активізації та успішного розвитку кредитування фізичних осіб банкам необхідно: знижувати кредитні ризики за рахунок відмови від агресивної кредитної політики, ретельної перевірки доходів позичальників; вдосконалювати внутрішню нормативну базу з питань кредитування фізичних осіб та ефективніше проводити роботу 3 позичальниками на всіх етапах кредитного процесу. За умов консервативного підходу до кредитування, наявності досвіду роботи в сегменті та якісного скорингу кредитний ризик може бути помірним. Подальший розвиток банківського кредитування фізичних осіб буде залежати від поліпшення фінансового стану самих фізичних осіб та збільшення споживчого попиту.

\section{Список використаної літератури}

1. Москальов А.А., Стельмах А.А. Сучасний стан та заходи стимулювання кредитування фізичних осіб в Україні.Scientific journal « $\Lambda$ ОГО $\Sigma$. The art of scientific mind». 2018. №1. С. 42-45.

2. Податковий кодекс України: Кодекс від 02.12.2010 р. № 2755-VI. URL: https://zakon.rada.gov.ua/laws/show/ 2755-17.

3. Цивільний кодекс України: Кодекс від 16.01.2013 р. № 435-IV. URL: https://zakon.rada.gov.ua/laws/show/ 435-15.

4. Савлук M.І., Мороз А.М., Пуховкіна М.Ф. Гроші та кредит: підручник. 3-тє вид., / за заг. ред. М.І. Савлука. К.: КНЕУ, 2002. 363 с.

5. Чайковський Я. І. Аналіз сучасного стану та перспективи розвитку банківського споживчого кредитування в Україні. Економічний аналіз: зб. наук. Тернопіль: Видавничо-поліграфічний центр «Економічна думка», 2017. Том 27. № 1. С. 156-163.

6. $\quad$ Про споживче кредитування: Закон України від 15.11.2016 p. № 1734VIII. URL: http://zakon3.rada.gov.ua/laws/ show/1734-19.

7. Про захист прав споживачів: Закон України від 12.05.1991 p. № 1023XII. URL: http://zakon3.rada.gov.ua/laws/ show/1023-12.

8. Звіт про фінансову стабільність: грудень 2018 року. Національний банк України. URL: https://bank.gov.ua/admin_uploads/article/FSR_2018R2.pdf?v=4.

9. Балансові звіти банків: офіційний сайт Національного банку України. URL:https://bank.gov.ua/control/uk/publish/article?art_id=34661442\&cat_id=34798 
593.

10. Грошово-кредитна та фінансова статистика: офіційний сайт Національного банку України. URL: https://bank.gov.ua/control/uk/publish/article? art_id=27843415\&cat_id=44578\#1.

11. Про внесення змін до деяких законів України з метою подолання негативних наслідків фінансової кризи: Закон України від 23.06.2009 № 1533-VI. URL: https://zakon.rada.gov.ua/laws/show/ 1533-17. 